\title{
A case with IGG4-related retroperitoneal fibrosis-periaortitis rapidly diagnosed and dramatically responded to steroid treatment
}

\author{
Y Karaaslan ${ }^{1,2^{*}}$, Z Ozbalkan Aslar ${ }^{2}$, S Can Sandikci ${ }^{2}$ \\ From 8th International Congress of Familial Mediterranean Fever and Systemic Autoinflammatory Diseases \\ Dresden, Germany. 30 September - 3 October 2015
}

\begin{abstract}
Background
Retroperitoneal fibrosis is a rare disease characterized by development of fibro-inflammatory tissue, which surrounds and causes compression of the retroperitoneal structures such as abdominal aorta, iliac vessels, vena cava and ureters $^{1}$. It's prevalence was reported as $1.4 / 100,000^{2}$. It has been recently shown that it is one of the IgG4-related disorders ${ }^{3}$. Herein, we report a male patient who admitted to emergency department with acute abdominal pain, diagnosed with IgG4-related retroperitoneal fibrosis-periaortitis in a very short time, and both high baseline serum creatinine level as well as abdominal pain requiring opioids on admission improved with steroids.
\end{abstract}

\section{Case}

Forth-one-year-old male admitted to emergency department with the complaint of abdominal pain. Wall of abdominal aorta seemed thickened on ultrasonography (USG). Abdominal computerized tomographic angiography showed soft tissues surrounding aorta, beginning 9 cmproximal to iliac bifurcation and continuing up to the level of common iliac artery (aortitis? retroperitoneal fibrosis?), and the patient was referred to rheumatology clinic. The patient was hospitalized for further investigations. He did not complain of fever, fatigue, or urinary symptoms. The blood tests revealed the following: Erythrocyte sedimentation rate (ESR) $57 \mathrm{~mm} / \mathrm{h}$, CRP $43 \mathrm{mg} / \mathrm{L}$, HGB $14.1 \mathrm{~g} / \mathrm{dL}$, WBC count $9800 / \mu \mathrm{L}$, PLT count $306000 / \mu \mathrm{L}$, MCV $82.3 \mathrm{fL}$, creatinine $1.15 \mathrm{mg} / \mathrm{dL}$ and ALT $18 \mathrm{U} / \mathrm{L}$. The urinalysis of the patients was normal, and he was negative for ANA, ANCA and ENA. His IgM was $128 \mathrm{mg} / \mathrm{dL}$ (46-304), IgG was $2060 \mathrm{mg} / \mathrm{dL}$ (751-1560),
IgA was $415 \mathrm{mg} / \mathrm{dL}$ (82-453), IgG 1 was $10700 \mathrm{mg} / \mathrm{L}$ (38249286), $\mathrm{IgG}_{2}$ was $9070 \mathrm{mg} / \mathrm{L}$ (2418-7003), IgG $\mathrm{Ig}_{3}$ was 1400 $\mathrm{mg} / \mathrm{L} \mathrm{(218-1761)} \mathrm{and} \mathrm{IgG}_{4}$ was $3550 \mathrm{mg} / \mathrm{L}$ (39.2-864). $\mathrm{IgG}_{4} /$ total IgG ratio was $17.2 \%$. Aortoiliac arterial Doppler USG showed that the soft tissue surrounded the left ureter completely and the right ureter partially, and it caused grade 1 hydronephrosis and obstructive volume increase in the left kidney. The patient was diagnosed with IgG4 related disease and retroperitoneal fibrosis, and administered $60 \mathrm{mg}$ methyl prednisolone as well as amlodipine due to high blood pressure. Venous and colored arterial Doppler examinations of the lower extremities were normal. The patient needed narcotic analgesics due to severe abdominal pain at the time of hospitalization. His abdominal pain improved with steroids in one week, and his ESR, CRP and creatinine levels decreased. ESR was $7 \mathrm{~mm} / \mathrm{h}$, and serum creatinine was $0.84 \mathrm{mg} / \mathrm{dL}$ at the second week of the treatment. The patient was discharged from the hospital with steroids, amlodipine, and PPI, and called for follow up visit 2 weeks later.

We did not biopsy the lesion since history, radiological findings and blood tests were characteristic for $\operatorname{IgG}_{4}$ mediated retroperitoneal fibrosis-periaortitis. Most of the cases with $\operatorname{IgG}_{4}$ mediated retroperitoneal fibrosis reported in the literature had a long diagnostic delay. Our patient is interesting since he was diagnosed with the disease shortly after beginning of his symptoms, steroids were administered immediately, and he responded steroids dramatically.

\section{Consent to publish}

Written informated consent for publication of their clinical details was obtained from the patient/parent/guardian/ relative of the patient.

\footnotetext{
${ }^{1}$ Hitit University Medical Faculty, Rheumatology, Çorum, Turkey

Full list of author information is available at the end of the article
} 


\section{Authors' details}

${ }^{1}$ Hitit University Medical Faculty, Rheumatology, Corum, Turkey. ${ }^{2}$ Ankara

Numune Education and Research Hospital, Rheumatology, Ankara, Turkey.

Published: 28 September 2015

\section{References}

1. Vaglio A, Salvarani C, Buzio C: Retroperitoneal fibrosis. Lancet 2006, 367(9506):241-51.

2. Thongprayoon C, Spanuchart I, Cheungpasitporn W, et al: Idiopathic retroperitoneal fibrosis: a challenging case in a rare disease. $N$ Am J Med Sci 2014, 6(5):237-8, doi: 10.4103/1947- 2714.132945.

3. Chiba K, Kamisawa T, Tabata T, et al: Clinical features of 10 patients with IgG4-related retroperitoneal fibrosis. Intern Med 2013, 52(14):1545-51, Epub 2013 Jul 15.

doi:10.1186/1546-0096-13-S1-P2

Cite this article as: Karaaslan et al:: A case with IGG4-related retroperitoneal fibrosis-periaortitis rapidly diagnosed and dramatically responded to steroid treatment. Pediatric Rheumatology 2015 13(Suppl 1): P2.

Submit your next manuscript to BioMed Central and take full advantage of:

- Convenient online submission

- Thorough peer review

- No space constraints or color figure charges

- Immediate publication on acceptance

- Inclusion in PubMed, CAS, Scopus and Google Scholar

- Research which is freely available for redistribution

Submit your manuscript at www.biomedcentral.com/submit 